\title{
Beta adrenoceptor binding and induced relaxation in airway smooth muscle from patients with chronic airflow obstruction
}

\author{
CHRIS J van KOPPEN, JAAP F RODRIGUES de MIRANDA, ARIE J BELD, \\ CEES L A van HER WAARDEN, JAN-WILLEM J LAMMERS, \\ CEES A M van GINNEKEN
}

From the Departments of Pharmacology and Pulmonary Diseases, University of Nijmegen, Nijmegen, The Netherlands

ABSTRACT Beta adrenoceptor function in central airway smooth muscle of patients with chronic airflow obstruction was investigated by radioligand binding studies and isoprenaline relaxation experiments. Receptor characteristics were determined in tracheal smooth muscle preparations obtained at necropsy from 12 patients and in bronchial tissue obtained at thoracotomy from $210_{0}^{\circ}$ patients with chronic airflow obstruction. Receptor characteristics were compared with those obtained in airway tissue preparations from 65 control subjects without chronic airflow obstruction The number of beta adrenoceptors, their binding affinity for the radioligand $\left[{ }^{125} \mathrm{I}\right]-(-)$-cyanopindolol and the tissue binding characteristics of isoprenaline were similar in tissue from patients with chronicon airflow obstruction and from control subjects. Isoprenaline induced relaxation of tracheal smooth $\mathbb{D}$ muscle without precontraction by methacholine showed slightly (though not significantly) less $\rightarrow$ sensitivity to isoprenaline in patients with chronic airflow obstruction than in control subjects (mean (SEM) $\mathrm{pD}_{2}$ - the negative logarithm of the concentration producing $50 \%$ relaxation-6.32 $(0 \cdot 16) \mathrm{p}$ $6.62(0 \cdot 15))$. The same pattern of $\mathrm{pD}_{2}$ values was found in segmental bronchial strips withou? precontraction by methacholine (chronic airflow obstruction $6.55(0 \cdot 27)$, control $7 \cdot 14(0 \cdot 12))$ Isoprenaline relaxation in segmental bronchial strips when contracted maximally was significantly less in the patients with airflow obstruction than in the control subjects $\left(\mathrm{pD}_{2}\right.$ value $5.99(0.18) v 6.45^{\alpha}$ $(0.07))$. These results suggest that beta adrenoceptors in airway smooth muscle of patients with $\underline{B}$. chronic airflow obstruction are not abnormal in number or in binding affinity but that there is lessi effective coupling between components of the relaxant system distal to the beta adrenoceptor. The possibility that the reduced isoprenaline sensitivity is a consequence of previous bronchodilatoro treatment cannot be excluded.

\section{Introduction}

Bronchial hyperreactivity in asthma or chronic obstructive bronchitis and emphysema may originate from an autonomic imbalance between the contracting muscarinic cholinergic and alpha adrenergic systems and the relaxing beta adrenergic and nonadrenergic, non-cholinergic systems.

Address for reprint requests: Dr Jaap F Rodrigues de Miranda, Department of Pharmacology, University of Nijmegen, PO Box 9101 , 6500 HB Nijmegen, The Netherlands.

Accepted 19 October 1988
In 1968 Szentivanyi' postulated that beta adreno ceptor dysfunction was one mechanism underlying bronchial hyperreactivity. This hypothesis was basedu on experiments on mice and rats vaccinated with Bordetella pertussis, which showed reduced sensitivity to catecholamines and certain responses that were comparable to those found in patients with asthmas The hyperreactivity following vaccination could also be observed after beta adrenoceptor blockadeō Subsequently other supporting evidence was found from animal models of asthma, particularly in guinead pigs. A reduced density of beta adrenoceptors ${ }^{2-5}$ an $\mathcal{f}^{2}$ diminished relaxation responses to beta adrenergic 
agonists $^{46}$ were found in airway tissue of sensitised guinea pigs.

The aim of the present study was to investigate beta adrenoceptors in patients with chronic airflow obstruction by means of receptor binding studies and relaxation experiments on tracheal and bronchial airway smooth muscle tissue. We determined the density of receptors by measuring binding of the radiolabelled (beta adrenergic antagonist $\left[{ }^{125} \mathrm{I}\right]$ (-)-cyanopindolol, here referred to as ${ }^{125} \mathrm{I}$-cyanopindolol) and studied beta adrenergic agonist binding in isoprenaline- ${ }^{125}$ I-cyanopindolol competition experiments.

The shallow beta adrenergic antagonist competition curves, which extend over a large concentration range of the agonist, reflect the existence of two agonist states of the beta adrenoceptor: one state with high and one with low affinity for agonists. The high affinity state is thought to be a ternary complex of agonist, receptor, and a stimulatory guanine nucleotide binding protein (Gs), ${ }^{7}$ and to be primarily concerned with the activation of adenylate cyclase, whereas the low affinity state represents a binary complex of agonist and receptor. The isoprenaline- ${ }^{125} \mathrm{I}$-cyanopindolol competition curves of patients with airflow obstruction were therefore analysed in terms of high and low affinity states and compared with competition curves from control subjects without chronic airflow obstruction.

In addition to the binding studies, we investigated beta adrenoceptor mediated relaxation responses in tracheal and bronchial smooth muscle strips. Airway smooth muscle relaxation is known to be an inverse function of initial smooth muscle tone, ${ }^{89}$ so inadequate function of the beta adrenoceptor system might be apparent only when smooth muscle tone is increased. We therefore determined the responsiveness of bronchial smooth muscle preparations to isoprenaline at varying levels of muscular tone induced by the muscarinic agonist methacholine.

\section{Methods}

\section{PATIENTS}

Tracheal tissue (necropsy) Tracheal tissue was obtained at necropsy within 24 hours of death from 44 control subjects without any record of respiratory disease (mean (SD) age $60(20)$ years, necropsy delay 14 (8) hours) and 12 patients with severe chronic airflow obstruction (age 66 (13) years, necropsy delay 17 (SD 6) hours) (table)). The diagnosis was made in accordance with the standards of the American Thoracic Society ${ }^{10}$ and was based on the medical history of the patient and morphological investigation of the lung. All patients with chronic airflow obstruction had morphological evidence of emphysema and nine of these patients in addition had symptoms of chronic bronchitis. Only two patients had shown an increase in $\mathrm{FEV}_{1}$ of $15 \%$ or more after inhalation of salbutamol. All but one of the patients had received bronchodilators (theophylline, salbutamol) in variable doses and prednisolone in the week preceding death.

Bronchial tissue (surgery) Bronchial tissue was obtained from 21 control patients and 21 patients with chronic airflow obstruction undergoing thoracotomy for bronchial carcinoma (table). Lung function indices were usually determined one week or less before surgery. None of the patients with chronic airflow obstruction showed an increase of $15 \%$ or more in

Characteristics (mean (SD)) of the patients

\begin{tabular}{|c|c|c|c|c|c|c|}
\hline \multirow[b]{2}{*}{ Source } & \multirow[b]{2}{*}{ Diagnosis } & \multirow[b]{2}{*}{ Age (y) } & \multicolumn{4}{|c|}{ Lung function indices ( $l$, with \% predicted ${ }^{23}$ in square brackets) } \\
\hline & & & $T L C$ & $V C$ & $F E V_{1}$ & $F E V_{1} / V C$ \\
\hline \multirow{5}{*}{$\begin{array}{l}\text { NECROPSY } \\
\text { Tracheal smooth } \\
\text { muscle } \\
\text { sURGERY } \\
\text { Group } A \\
\text { Main bronchus } \\
\text { smooth muscle } \\
\text { (receptor } \\
\text { binding) }\end{array}$} & CAO & $66(13)$ & $6.4(1.0)$ & $3.4(0.8)$ & $1.2(0.4)$ & $36(12)$ \\
\hline & $(n=12)$ & & {$[106(18)]$} & [87(17)] & {$[45(15)]$} & \\
\hline & & & & & & \\
\hline & $\begin{array}{l}\text { Control } \\
(n=1)\end{array}$ & 58 & $5.4[100]$ & $3 \cdot 5[112]$ & $2 \cdot 5[100]$ & 71 \\
\hline & $\begin{array}{l}\mathrm{CAO} \\
(\mathrm{n}=3)\end{array}$ & $61(7)$ & $\begin{array}{l}6.4(2.0) \\
{[128(37)]}\end{array}$ & $\begin{array}{l}3.6(1.0) \\
{[83(19)]}\end{array}$ & $\begin{array}{l}2 \cdot 1(0 \cdot 7) \\
{[65(22)]}\end{array}$ & $57(4)$ \\
\hline \multirow{2}{*}{$\begin{array}{l}\text { Group B } \\
\text { Lobar and } \\
\text { segmental } \\
\text { bronchial tissue } \\
\text { (receptor binding) }\end{array}$} & Controls & $58(17)$ & \multirow{2}{*}{$\begin{array}{l}6 \cdot 6(1 \cdot 3) \\
{[107(29)]} \\
6 \cdot 2(0 \cdot 9) \\
{[92(11)]}\end{array}$} & \multirow{2}{*}{$\begin{array}{l}4 \cdot 0(0 \cdot 8) \\
{[107(15)]} \\
3.6(0 \cdot 5) \\
{[87(10)]}\end{array}$} & \multirow{2}{*}{$\begin{array}{l}2 \cdot 8(0 \cdot 5) \\
{[95(11)]} \\
2 \cdot 0(0 \cdot 3) \\
{[65(6)]}\end{array}$} & $70(7)$ \\
\hline & $\begin{array}{l}(n=9) \\
\mathrm{CAO} \\
(\mathrm{n}=8)\end{array}$ & $63(8)$ & & & & $56(2)$ \\
\hline \multirow{2}{*}{$\begin{array}{l}\text { Group } C \\
\text { Segmental } \\
\text { bronchial tissue } \\
\text { (relaxation) }\end{array}$} & Controls & $63(14)$ & \multirow{2}{*}{$\begin{array}{l}6 \cdot 3(1 \cdot 8) \\
{[97(18)]} \\
6 \cdot 2(1 \cdot 5) \\
{[92(13)]}\end{array}$} & \multirow{2}{*}{$\begin{array}{l}4 \cdot 1(0 \cdot 9) \\
{[105(17)]} \\
3 \cdot 5(1 \cdot 1) \\
{[84(22)]}\end{array}$} & \multirow{2}{*}{$\begin{array}{l}2 \cdot 8(0.8) \\
{[96(15)]} \\
2 \cdot 0(0 \cdot 7) \\
{[62(17)]}\end{array}$} & $68(7)$ \\
\hline & $\begin{array}{l}(\mathrm{n}=11) \\
\mathrm{CAO} \\
(\mathrm{n}=10)\end{array}$ & & & & & $56(5)$ \\
\hline
\end{tabular}

TLC - total lung capacity; VC-vital capacity; $\mathrm{FEV}_{1}$ - forced expiratory volume in one second; CAO_chronic airflow obstruction. 
$\mathrm{FEV}_{1}$ after inhalation of salbutamol. Beta adrenoceptors in bronchial tissue were investigated either by radioligand binding or by relaxation experiments in tissue samples of different groups of patients (A, B, or C), as the amount of tissue we received was usually too small to allow both types of experiments on tissue from the same patient. In the week preceding the operation most patients received bronchodilator drugs and prednisolone, usually until the day of surgery. All patients received narcotics, analgesics, atropine, and muscle relaxants during surgery.

\section{TISSUE PREPARATION AND RECEPTOR BINDING EXPERIMENTS}

Smooth muscle from the trachea and main bronchi was prepared as described previously." Briefly, after removal of the mucosa, the tracheal smooth muscle layer was clearly visible and freed from adhering connective tissue. The smooth muscle was then minced with a pair of scissors and homogenised with carborundum in a mortar at $0^{\circ} \mathrm{C}$. The tissue pulp was

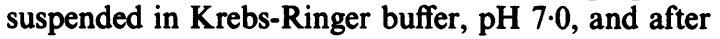
differential centrifugation the resulting $100000 \mathrm{~g}$ membrane pellet was stored at $-80^{\circ} \mathrm{C}$. Lobar and segmental bronchi were dissected out of the external lung parenchyma, freed from mucus, and cut open. A crude bronchial tissue sample containing epithelium, smooth muscle, submucosal glands, and connective tissue was obtained by scraping the bronchial wall with a scalpel until the surrounding cartilage was visible. This preparation was homogenised with carborundum and processed as described above. Beta adrenoceptor binding characteristics were studied with ${ }^{125} \mathrm{I}$-cyanopindolol (specific activity, $81 \times 10^{12} \mathrm{~Bq} /$ mmol, New England Nuclear Europe) as radioligand. The binding procedure for tracheal smooth muscle membranes was as described previously. ${ }^{12}$ For the determination of the binding properties of ${ }^{125} \mathrm{I}$-cyanopindolol in smooth muscle from main bronchi, and from lobar and segmental bronchi we used a double receptor assay ${ }^{13}$ in which beta adrenoceptor density was measured simultaneously with muscarinic receptor density.

For accurate determination of the muscarinic receptor density with the tritiated muscarinic radioligand quinuclidinyl benzilate it was necessary to reduce the specific activity of ${ }^{125} \mathrm{I}$-cyanopindolol about one order of magnitude by dilution with unlabelled $( \pm)$ iodocyanopindolol (kindly provided by $\mathrm{Dr}$ G Engel, Sandoz, Basel, Switzerland). Incubation of tracheal and bronchial membranes was carried out in KrebsRinger buffer, $\mathrm{pH} 7.0$ at $37^{\circ} \mathrm{C}$ for 90 minutes and terminated by centrifugation at $18000 \mathrm{~g}$ for 15 minutes or by filtration through Whatman $G F / C$ filters followed by washing. In concentration dependent ${ }^{125}$ I-cyanopindolol binding experiments the ligand concentration ranged from 5 to $80 \mathrm{pmol} / \mathrm{l}$. Isoprenaline competition experiments were done with a fixed ${ }^{125} \mathrm{I}$-cyanopindolol concentration in the range $\vec{\Rightarrow}$ 5-14 pmol/1 in the presence of the protease inhibitor $\stackrel{5}{\rightarrow}$ phenylmethylsulphonylfluoride (Sigma) $0.1 \mathrm{mmol} / 1$ 읃 and ascorbic acid (Merck) $1 \mathrm{mmol} / 1$ to counteract 흠 oxidation of isoprenaline. Specific ${ }^{125} \mathrm{I}$-cyanopindolol $\frac{\omega}{\vec{D}}$ binding was defined as the difference between binding $\stackrel{\square}{\square}$ in the absence and in the presence of $1.0 \mu \mathrm{mol} / 1( \pm)-$ i propranolol. Binding parameters were calculated by a $\vec{\circ}$ non-linear least squares curve fitting program. ${ }^{14}$ The $\mathrm{pK}_{\mathrm{d}}$ value is the negative logarithm of the equilibrium $\vec{\omega}$ dissociation constant that corresponds to the radioligand concentration $(\mathrm{mol} / \mathrm{l})$ at which $50 \%$ of the $\vec{x}$ receptor population is occupied by radioligand. It is a measure of the affinity of the receptor for the radioligand. The $R_{T}$ value is the receptor density. In $\sim_{\infty}$ previous studies we observed no decline in $K_{d}$ and $R_{T}$ O up to 24 hours after death. ${ }^{12}$

\section{RELAXATION EXPERIMENTS}

Tracheal smooth muscle strips and spirally cut bronchial strips ${ }^{15}$ were relaxed isotonically with isoprenaline under a load of $0.5 \mathrm{~g}$ in Krebs-Henseleit buffer, $\mathrm{pH} \vec{\oplus}$ $7.4\left(37^{\circ} \mathrm{C}\right)$, supplemented with $5 \mathrm{mmol} / 1$ glucose and aerated with $5 \%$ carbon dioxide and $95 \%$ oxygen. After the responsiveness of the strips had been tested with $10^{-6} \mathrm{~mol} / 1 \mathrm{methacholine}$ followed by washing, cumulative dose-response curves for isoprenaline were recorded in the absence and in the presence of $10^{-6}$ or $\mathbb{D}$ $10^{-4} \mathrm{~mol} / 1$ methacholine. Preliminary experiments $\stackrel{\circ}{\Rightarrow}$ showed that contraction obtained with $10^{-4} \mathrm{~mol} / 1$ 응 methacholine was stable for the period required to construct a complete relaxation curve. The recording of an isoprenaline relaxation curve and subsequent washing took about three hours. Tracheal smooth muscle responses were measured in two or three strips $\stackrel{0}{\vec{D}}$ in duplicate. Relaxation responses of segmental bronchial strips were determined in duplicate when 3 possible, either in the same preparation or in two different strips. The $\mathrm{pD}_{2}$ values and Hill coefficients $\left(\mathrm{n}_{\mathrm{H}}\right)$ were calculated as described previously. ${ }^{.1}$ The $\mathrm{pD}_{2}$ 응 value is the negative logarithm of the concentration (mol/l) producing half maximal relaxation while the $\mathrm{n}_{\mathrm{H}}$ 음 value represents the slope of the Hill plot and is a quantitative measure for the steepness of the log dose- - r relaxation curve. Isoprenaline was dissolved in dis- $N$ tilled water containing $6 \mathrm{mmol} / \mathrm{l}$ ascorbic acid.

We investigated the influence of delay in the post- $\omega$ mortem examination on isoprenaline $\mathrm{pD}_{2}$ and $\mathrm{n}_{\mathrm{H}}$ values in tracheal smooth muscle strips of control? subjects, but no correlation was found (r values $-0 \cdot 18 \stackrel{\leftrightarrow}{\rightarrow}$ and 0.31 respectively; $n=12$ ).

\section{MOR PHOMETRIC ANALYSIS}

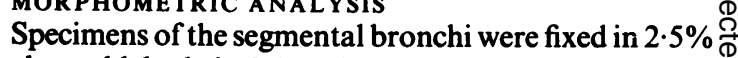
glutaraldehyde in $0.1 \mathrm{~mol} / 1$ phosphate buffer, $\mathrm{pH} \mathrm{7.0,}$ dehydrated in ethanol, and embedded in glycolmethacrylate (JB4 embedding kit, Polysciences Inc, 8 Warrington, Pennsylvania, USA). Sections were 
stained with toluidine blue ( $2 \%)$. The relative proportions of submucosal glands and smooth muscle as percentages of total bronchial area were determined according to the method of Restrepo and Heard. ${ }^{16}$

\section{STATISTICAL ANALYSIS}

Isoprenaline competition curves were fitted to a one or two binding site model. Preference was given to the two binding site model when a significant diminution in the residual sum of squares was reached (F test). ${ }^{17}$ Student's $t$ test ${ }^{18}$ was used to assess the significance of differences in the negative logarithm of the dissociation constants $\left(\mathrm{pK}_{\mathrm{d}}, \mathrm{pK}_{\mathrm{H}}\right.$, and $\left.\mathrm{pK}_{\mathrm{L}}\right)$ and the percentage of receptors in the high affinity state $\left(\% R_{H}\right)$.

Differences in $\mathrm{pD}_{2}$ values, $\mathrm{R}_{\mathrm{T}}$ values, Hill coefficients, and morphometrically determined areas between tissue from control subjects and tissue from patients with chronic airflow obstruction were compared by the Wilcoxon rank sum test. ${ }^{18}$ For paired observations (that is, $\mathrm{pD}_{2}$ values in fig $5, a$ and $b$ ) Student's paired $t$ test $^{18}$ was used. Significance was accepted at $\mathrm{p}<0.05$.

\section{Results}

\section{BETA ADRENOCEPTOR CHARACTERISTICS IN SMOOTH MUSCLE OF TRACHEA AND MAIN BRONCHUS}

The beta adrenoceptor numbers and affinities for ${ }^{125} \mathrm{I}$ cyanopinodolol in central airway smooth muscle from patients with chronic airflow obstruction (table: necropsy and surgery group A) were well within the range of values obtained in the control subjects (fig 1). The binding characteristics of the beta adrenergic agonist isoprenaline assessed in ${ }^{125}$ I-cyanopindolol competition experiments were unaltered (fig 2).

Isoprenaline relaxation responses in tracheal smooth muscle strips were similar in the patients and control subjects (fig 3 ). The preparations from patients with chronic airflow obstruction had $\mathrm{pD}_{2}$ values in the lower range of the control values but the difference between mean values was not significant. There was no significant correlation between the isoprenaline $\mathrm{pD}_{2}$ values and beta adrenoceptor density on smooth muscle $(r=0 \cdot 20, n=9)$. In the two patients with the lowest $\mathrm{pD}_{2}$ values the unfavourable ratio of specific to non-specific binding of the radioligand precluded measurement of isoprenaline binding. The Hill coefficients $(\mathrm{nH})$ were similar in the two groups and close to $1 \cdot 0$.

\section{BETA ADRENOCEPTOR CHARACTERISTICS IN} LOBAR AND SEGMENTAL BRONCHIAL TISSUE

${ }^{125}$ I-cyanopindolol binding The number and affinities of beta adrenoceptors in bronchial tissue of control subjects and patients with chronic airflow obstruction (table: surgery group $B$ ) were similar $\left(R_{T}\right.$ values 376 (SEM 64) and $372(69) \mathrm{fmol} / \mathrm{g}$ tissue; $\mathrm{pK}_{\mathrm{d}}$ values 11.22 (SEM 0.05) and 11.34 (0.05)). Beta adrenoceptors in human bronchi are located in epithelium, smooth muscle, and submucosal glands. ${ }^{19}$ The areas of submucosal glands and smooth muscle tissue in patients with chronic airflow obstruction and control subjects appeared to be of similar magnitude: $13.0 \%$ (SEM
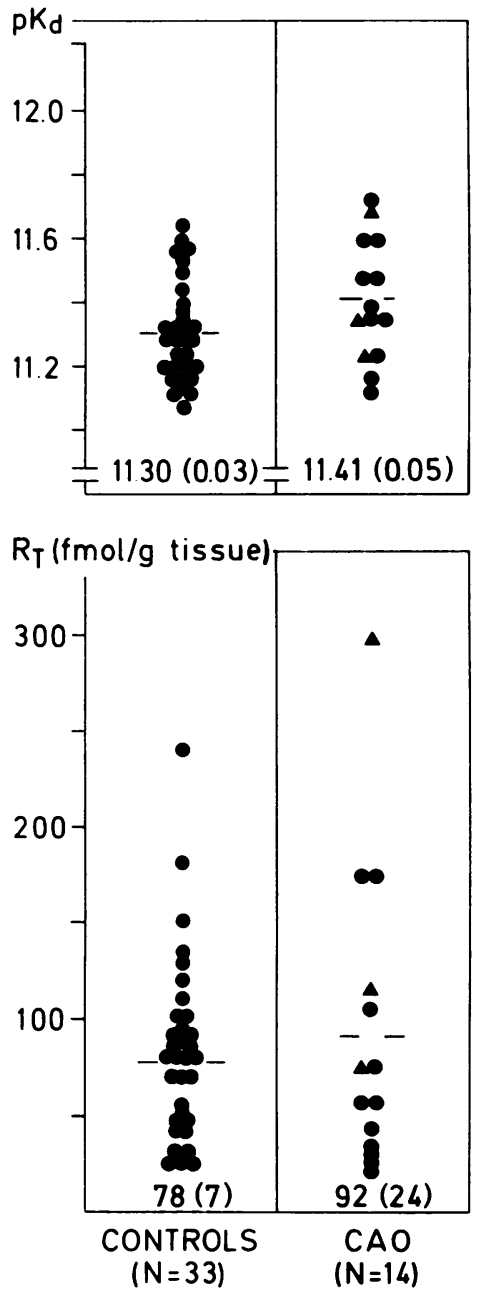

Fig $1{ }^{125}$ I-cyanopindolol binding characteristics in smooth muscle membranes from trachea ( ) and main bronchi $(\Delta)$. Individual values of receptor density $\left(R_{T}\right)$ and binding affinity $\left(p K_{d}\right)$ expressed as the negative logarithm of the dissociation constant $\left(K_{d}\right)$ are given. The data refer to the patients listed in the table under "Necropsy group" and "Surgery group A." Horizontal bars indicate mean values. The mean and SEM are given at the bottom of each column. Binding indices in patients with chronic airflow obstruction (CAO) were not significantly different from control values. 

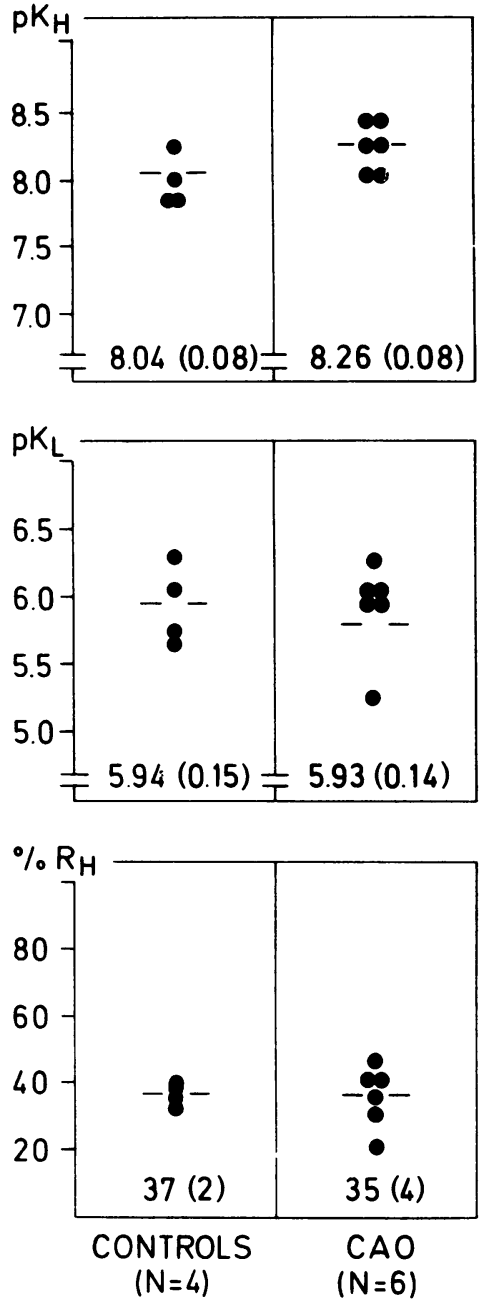

Fig 2 Isoprenaline binding characteristics in tracheal smooth muscle membranes. Binding characteristics were determined in ${ }^{125}$ I-cyanopindolol competition experiments. All curves could be fitted adequately to a model of two affinity states of the receptors, $R_{H}$ and $R_{L}$, with corresponding affinity constants expressed as $p K_{H}$ and $p K_{L}$. The relative proportion of the high affinity state is given as percentage of specific binding $\left(\% R_{H}\right)$. Individual values are given. Horizontal bars indicate mean values. The mean and SEM are given at the bottom of each column. Binding characteristics in patients with chronic airflow obstruction (CAO) were not significantly different from control values.

$1.6 \%)$ and $7.2 \%(1.7 \%) v 13.2 \%(2.1 \%)$ and $8.8 \%$ $(1 \cdot 3 \%)$.

\section{ISOPRENALINE INDUCED RELAXATION}

The bronchial strips from patients with chronic airflow obstruction showed a considerable variability in their sensitivity to isoprenaline. Half of the patients with chronic airflow obstruction had lower $\mathrm{pD}_{2}$ values than the control subjects (fig 4). The difference in mean $\mathrm{pD}_{2}$ values, however, did not reach significance. There was no significant correlation between $\mathrm{pD}_{2}$ values and the degree of bronchial obstruction (that is, FEV as percentage of predicted value) $(r=0.32)$ or the reversibility of obstruction - that is, increase in FEV, after inhalation of salbutamol $(r=0 \cdot 19)$.

\section{FUNCTIONAL ANTAGONISM}

To investigate the balance between the muscarinic and beta adrenergic receptor systems, the sensitivity of segmental bronchial strips to isoprenaline at different degrees of methacholine induced tone was studied. Precontraction of smooth muscle strips with $10^{-6}$ or $10^{-4} \mathrm{~mol} / \mathrm{l}$ methacholine resulted in a rightward shift of the isoprenaline dose-relaxation curves in control subjects (fig $5 a$ ) and patients with chronic airflow obstruction (fig $5 b$ ). Moreover, the variability in $\mathrm{pD}_{2}$ values decreased with increased smooth muscle tone. The relaxation curves recorded in the presence of $10^{-6}$ and $10^{-4} \mathrm{~mol} / \mathrm{l}$ methacholine were similar in the
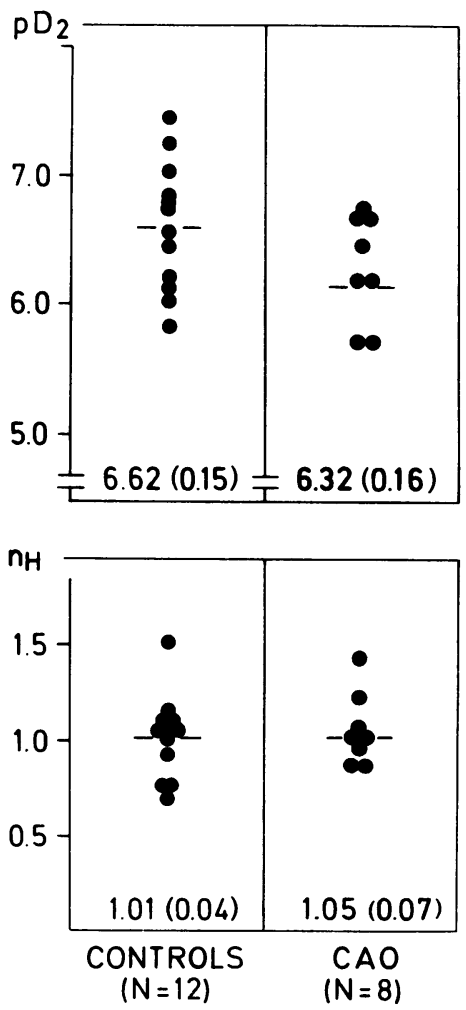

Fig 3 Isoprenaline induced relaxation of tracheal smooth muscle without precontraction by methacholine. Individual $\mathrm{pD}_{2}$ values and Hill coefficients $\left(n_{H}\right)$ are given. Horizontal bars indicate mean values and the mean and SEM are given at the bottom of each column. Relaxation responses of patients with chronic airflow obstruction (CAO) were not significantly different from control values. 

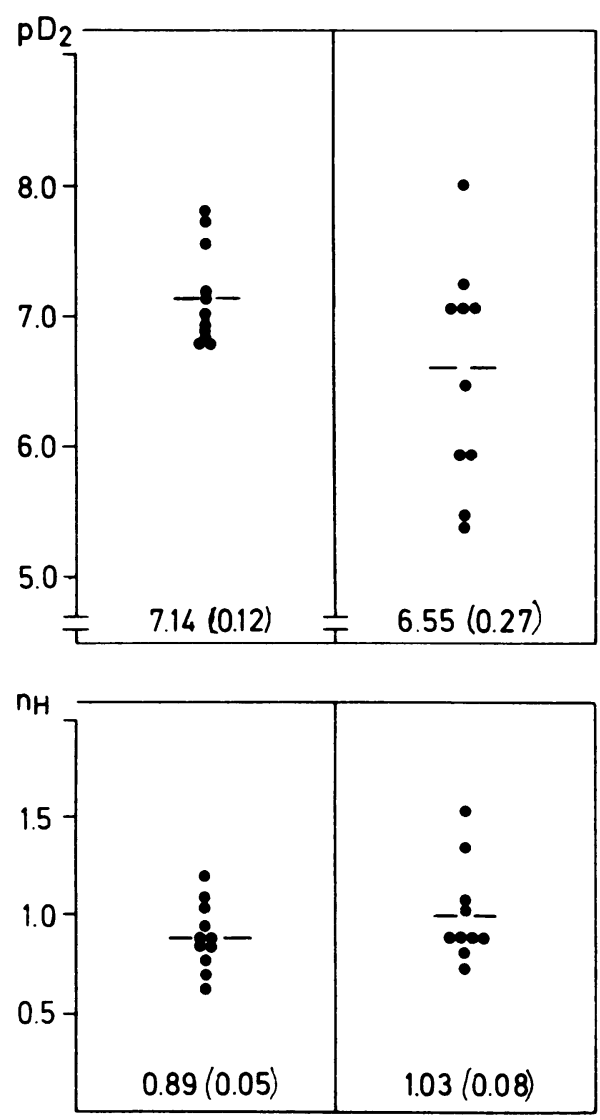

Fig 4 Isoprenaline induced relaxation of segmental bronchial strips without precontraction by methacholine. Individual $p D_{2}$ values and Hill coefficients $\left(n_{H}\right)$ are given, and horizontal bars indicate mean values. The mean and SEM are given at the bottom of each column. The mean $p D_{2}$ values and $\left(n_{H}\right)$ Hill coefficients of patients with chronic airflow obstruction (CAO) were not significantly different from control values.

two study groups. The relaxation curves of the patients, however, appeared to shift to higher isoprenaline concentrations than those of control subjects. The mean isoprenaline $\mathrm{pD}_{2}$ value of maximally contracted smooth muscle strips of patients with chronic airflow obstruction (5.99 (SEM 0.18)) was significantly lower than that of control subjects $(6.45(0.07))(p$ $<0.05$ ). In both groups maximal contraction induced by methacholine could be completely reversed by isoprenaline.

\section{Discussion}

The objective of the present study was to investigate beta adrenoceptor function in airway smooth muscle of patients with chronic airflow obstruction. The rationale for the study was the theory of Szentivanyi ${ }^{1}$ that beta adrenoceptor dysfunction is an underlying abnormality in asthma, for which evidence has been found in animal models of asthma..$^{2-6}$ In patients with obstructive airflow disease, however, the beta adrenoceptors in tracheal smooth muscle appear to be present in normal density and to have normal antagonist (that is, ${ }^{125} \mathrm{I}$-cyanopindolol) and agonist (that is, isoprenaline) affinity. We chose tracheal smooth muscle to study airway smooth muscle beta adrenoceptors because it is homogeneous and can be obtained in sufficient amounts for radioligand binding studies. Theoretically, the finding of normal receptor characteristics in this smooth muscle preparation does not rule out the possibility that receptor changes might be present in smaller airways. This seems unlikely, however; in the animal studies ${ }^{46}$ reduced beta adrenoceptor numbers and relaxation responses were found also in tracheal smooth muscle.

Like tracheal smooth muscle, bronchial tissue from the patients with chronic airflow obstruction also showed normal ${ }^{125}$ I-cyanipindolol binding properties. The airway preparations used to measure beta adrenoceptors on smooth muscle cells from bronchi, however, suffer from the inclusion of other tissues that have beta adrenoceptors-namely, epithelium and submucosal glands. ${ }^{19}$ The proportion of tissue made up of submucosal glands and smooth muscle was, however, similar in patients with chronic airflow obstruction and control subjects, reducing the possibility that differences in other tissues might make a change in smooth muscle beta adrenoceptor numbers.

Airway smooth muscle from patients with chronic airflow obstruction showed a large variation in isoprenaline sensitivity and several patients had lower bronchial $\mathrm{pD}_{2}$ values than control subjects. The difference between patients' and control subjects' isoprenaline sensitivity, however, was statistically significant only when strips were maximally precontracted by methacholine. This may be because the small difference is not noticeable in non-precontracted bronchial strips owing to the large variability in intrinsic tone, but becomes perceptible when tone is increased by a reproducible stimulus, methacholine. This explanation is supported by the finding that the standard error of the isoprenaline $\mathrm{pD}_{2}$ values in maximally precontracted smooth muscle strips is two fold smaller than that of smooth muscle strips without precontraction by methacholine (see fig $5 a$ and $b$ ).

Our observations contrast with those of Taylor et $a l^{20}$ and Cerrina et al, ${ }^{21}$ who observed normal relaxation responses in bronchial strips from patients with airflow obstruction, including those with chronic airflow obstruction. This discrepancy may be related to the different recording conditions - that is, isotonic relaxations after precontraction with methacholine in our study compared with isometric recording under a load of 2-5 g and histamine as the contracting agent used by the other authors. Alternatively, different 


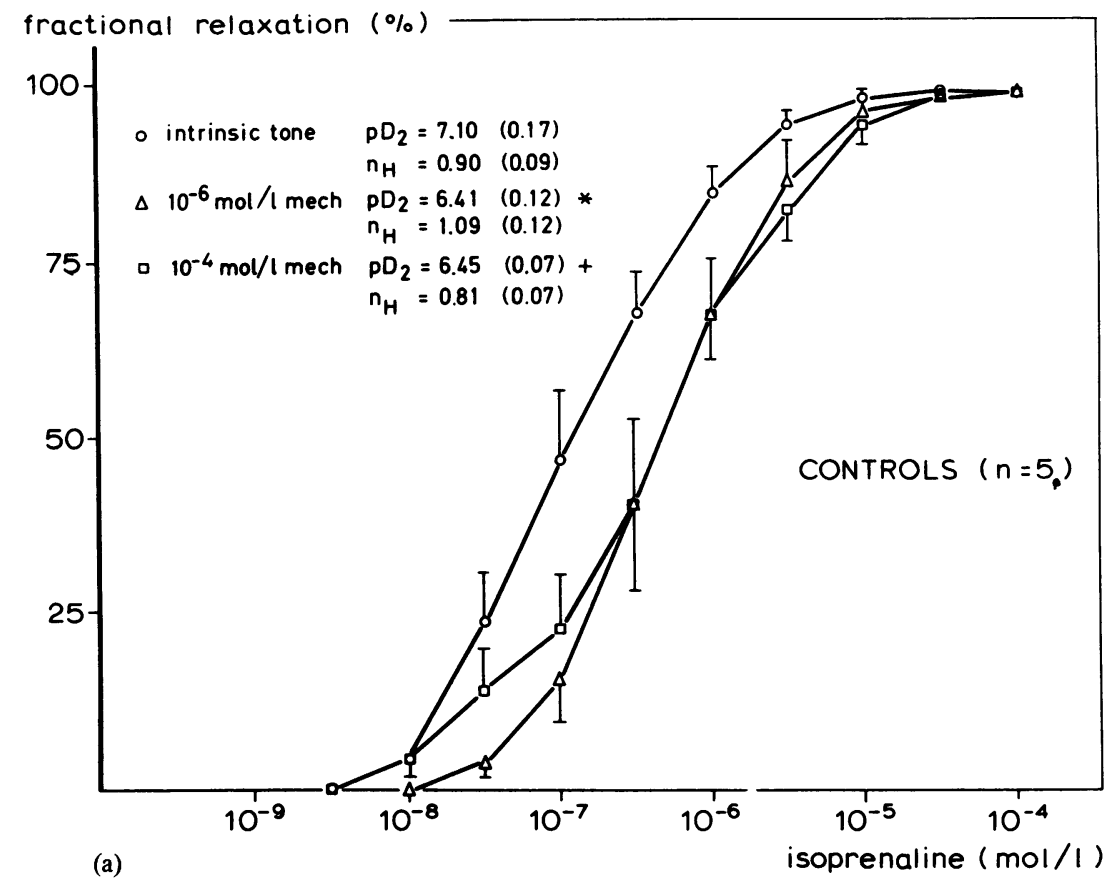

fractional relaxation $(\%)$

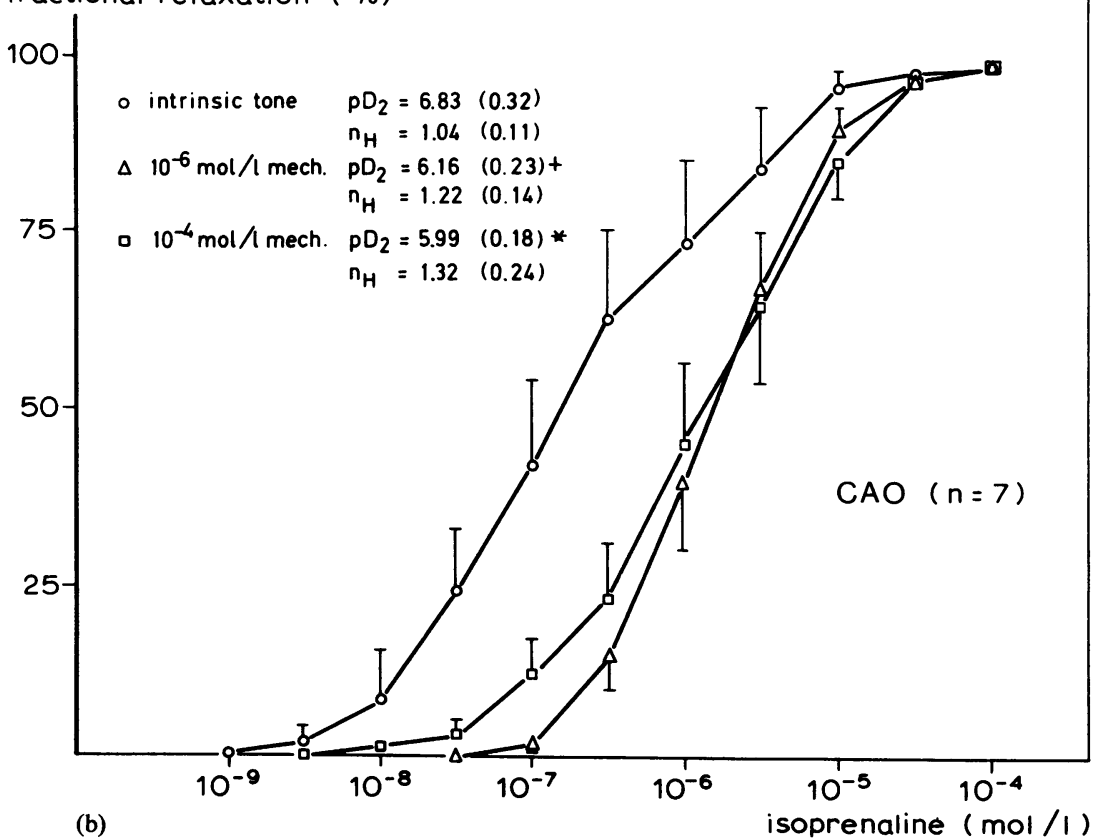

Fig 5 Isoprenaline dose-relaxation curves of segmental bronchial strips of control subjects (a) and patients with chronic airflow obstruction $(C A O)(b)$. The curves were recorded in the absence and in the presence of $10^{-6}$ and $10^{-4}$ mol/l methacholine (mech) (that is, relaxation from an "intrinsic tone," "half maximal," and "maximal precontraction" respectively). The $C A O$ group comprised seven patients from group $C$ (table 1). The maximal relaxation responses to isoprenaline in the presence of $10^{-4}$ mol/l methacholine were similar in strips of control subjects and patients with CAO: $120 \%$ (SEM 69\%) and $107 \%(52 \%)$ respectively, expressed as percentages of the maximal contraction response. Values given are means and SEM. *Significantly different from the $p D_{2}$ value determined in the absence of methacholine $(p<0 \cdot 05$, Student's $t$ test). $+0.05<p<0.10$. 
diagnostic criteria may underlie this discrepancy. The reduced isoprenaline sensitivity may be a consequence of previous treatment. Most patients with chronic airflow obstruction were treated with theophylline, salbutamol, and prednisolone to improve lung function before surgery. It is well established that exposure to beta adrenergic agonists and glucocorticosteroids may induce beta adrenoceptor changes and alterations in its coupling to stimulatory guanine nucleotide binding proteins. ${ }^{22}$

The reduced isoprenaline sensitivity suggests that in patients with chronic airflow obstruction vagally induced airway smooth muscle contraction may be compensated for to a lesser extent by circulating adrenaline than in healthy subjects. The results of the binding experiments, which showed unaltered antagonist and agonist binding profiles, suggest that the reduced isoprenaline sensitivity is not related to an impaired beta adrenoceptor or defective coupling to adenylate cyclase. We conclude that coupling between components of the relaxant system distal to the beta adrenoceptors is less effective. Further studies are required to determine whether the reduced isoprenaline sensitivity in chronic airflow obstruction is a drug induced desensitisation.

We thank Mrs C N Verrijp and Mr H G Mouris for excellent technical assistance, $F$ van den Elshout at the University Lung Centre (Dekkerswald) for clinical data, and Mrs $\mathrm{H}$ Janssen-Bruyns for typing the manuscript. We are indebted to the departments of pathology at the St Radboud Academic Hospital and the Canisius Wilhelmina Hospital for the supply of lung tissue. This research was financially supported by the Nederlands Astma Fonds (grant 82.23).

\section{References}

1 Szentivanyi A. The beta-adrenergic theory of the atopic abnormality in bronchial asthma. J Allergy 1968;42: 203-32.

2 Barnes PJ, Dollery CT, MacDermot J. Increased pulmonary $\alpha$-adrenergic and reduced $\beta$-adrenergic receptors in experimental asthma. Nature 1980; 285:569-71.

3 Mita H, Yui Y, Suzuki M, Yasueda H, Shida T. Effect of Bordetella pertussis on $\alpha_{1}$ and $\beta$-adrenergic and cholinergic muscarinic receptors in guinea pig lung membranes. Int Arch Allergy Appl Immunol 1982; 69:169-73.

4 Schreurs AJM, Nijkamp FP. Haemophilus influenzae induced loss of lung $\beta$-adrenoceptor binding sites and modulation by changes in peripheral catecholaminergic input. Eur J Pharmacol 1982;77:95-102.

5 Taki F, Takagi K, Satake T, Sugiyama S, Ozawa T. The role of phospholipase in reduced beta-adrenergic responsiveness in experimental asthma. Am Rev Respir Dis 1986;133:362-6.
6 Kaukel E, Rieckenberg B. Partial beta-adrenergic receptor blockage in experimental bronchial asthma. Biochem Biophys Res Commun 1980;96:1626-32.

7 Stiles GL, Caron MG, Lefkowitz RJ. $\beta$-adrenergic receptors: biochemical mechanisms of physiological regulation. Physiol Rev 1984;64:661-743.

8 Torphy TJ, Rinard GA, Rietow MG, Mayer SE. Functional antagonism in canine tracheal smooth muscle: inhibition by methacholine of the mechanical and biochemical responses to isoproterenol. J Pharmacol Exp Ther 1983;227:694-699.

9 Van den Brink FG. The model of functional interaction. II experimental verification of a new model: the antagonism of $\beta$-adrenoceptor stimulants and other agonists. Eur J Pharmacol 1973;22:279-86.

10 American Thoracic Society. Chronic bronchitis, asthma and pulmonary emphysema. Definitions and classification of chronic bronchitis, asthma and pulmonary emphysema. Am Rev Respir Dis 1962;85:762-8.

11 Van Koppen CJ, Rodrigues de Miranda JF, Beld AJ, et al. Characterization of the muscarinic receptor in human tracheal smooth muscle. NaunynSchmiedeberg's Arch Pharmacol 1985;331:247-52.

12 Van Koppen CJ, Hermanussen MW, Verrijp CN, et al. $\beta$ adrenoceptors in human tracheal smooth muscle: characteristics of binding and relaxation. Life Sci 1987;40:2561-70.

13 Van Koppen CJ, Siero HLM, Rodrigues de Miranda JF, Beld AJ, Ariëns EJ. Simultaneous assay of muscarinic and beta-adrenergic receptors using a double isotope technique. Biochem Biophys Res Commun 1984;120: 665-9.

14 Fletcher R, Powell MJD. A rapid convergent descent method for minimisation. Computer J 1963;6:163-8.

15 De Jongste JC, Van Strik R, Bonta IL, Kerrebijn KF. Measurement of human small airway smooth muscle function in vitro with the bronchiolar strip preparation. J Pharmacol Meth 1985;14:111-8.

16 Restrepo GL, Heard BE. Mucous gland enlargement in chronic bronchitis: extent of enlargement in the tracheo-bronchial tree. Thorax 1963;18:334-9.

17 Boxenbaum HG, Riegelman S, Elashoff RM. Statistical estimations in pharmacokinetics. $J$ Pharmacokinet Biopharmacol 1974;2:123-48.

18 Colton T. Statistics in medicine. 1st ed. Boston: Little, Brown and Company, 1974.

19 Carstairs JR, Nimmo AJ, Barnes PJ. Autoradiographic visualisation of $\beta$-adrenoceptor subtypes in human lung. Am Rev Respir Dis 1985;132:541-7.

20 Taylor SM, Paré PD, Armour CL, Hogg JC, Schellenberg RR. Airway reactivity in chronic obstructive pulmonary disease. Failure of in vivo methacholine responsiveness to correlate with cholinergic, adrenergic or nonadrenergic responses in vitro. Am Rev Respir Dis 1985;132:30-5.

21 Cerrina J, Le Roy Ladurie M, Labat C, Raffestin B, Bayol A, Brink C. Comparison of human bronchial muscle responses to histamine in vivo with histamine and isoproterenol agonists in vitro. Am Rev Respir Dis 1986;134:57-61.

22 Samuelson WM, Davies AO. Hydrocortisone-induced reversal of beta-adrenergic receptor uncoupling. Am Rev Respir Dis 1984;130:1023-6.

23 Quanjer PH, ed. Standardized lung function testing. Clin Respir Physiol 1983;19 (suppl 5):1-95. 